\title{
CONTACT-INDUCED FEATURES IN THE RUSSIAN SPEECH OF NGANASANS
}

\author{
Irina Khomchenkova \\ Lomonosov Moscow State University, Vinogradov Russian \\ Language Institute RAS, Institute of Linguistics RAS
}

\begin{abstract}
This paper investigates the variety of Russian spoken by the Nganasans, basing on the Nganasan Russian subcorpus of narratives from the larger corpus of contact-influenced Russian speech of Russian Far East and Northern Siberia. The study focuses on morphosyntactic phenomena, namely peculiarities in noun and verbal inflection, verbal derivation, preposition drop, non-standard verb argument encoding, gender disagreement and some others, that presumably are contact-induced - they could be explained by direct structural copying (with clear parallels in Nganasan) or by incomplete acquisition of Russian (with no clear parallels in Nganasan). The second aim of this paper is to speculate as to whether the varieties of Russian spoken in the 1990s (when the audiofiles were collected) by the Nganasans form a post-pidgin continuum, with Govorka as the basilect and Standard Russian as the acrolect.
\end{abstract}

Keywords: language contact, grammatical interference, corpus linguistics, Russian, Nganasan, Govorka, pidgin, Samoyedic

DOI: https://doi.org/10.12697/jeful.2020.11.2.01

\section{Introduction}

How speakers of indigenous languages of Russia use Russian has been lately one of the most promising topics, see, i.a. researches devoted to South Tungusic Russian (Stoynova in press), Erzya Russian (Shagal 2016), Daghestanian Russian (Daniel and Dobrushina 2013), Forest Enets Russian (Stoynova and Shluinsky 2010). In order to contribute to this field, I investigated the variety of Russian spoken by Nganasans, conducting mainly a descriptive analysis of morphosyntactic phenomena that presumably are contact-induced - providing an overview of a Russian language variety that has not been described yet. The study is based on the Nganasan subcorpus of narratives from the larger corpus 
of contact-influenced Russian speech of Russian Far East and Northern Siberia. ${ }^{1}$

It is worth noting that even though the paper is devoted to contactinduced features - features that could be explained by direct structural copying (with clear parallels in Nganasan) or by the incomplete acquisition of Russian (with no clear parallels in Nganasan) -, the distinction between these contact-induced features and non-contact-induced features (features that are regional/dialectal or typical of oral spontaneous speech, but nonstandard compared to written Russian) might be challenging. If the contact nature of some peculiarity is dubitable, noncontact explanations are mentioned as well.

Another problematic issue is Govorka, the Taimyr Pidgin Russian which was spoken by indigenous peoples of Taimyr (including the Nganasans) in the XIX-XX centuries (Stern 2005, 2012). In my Nganasan subcorpus two speakers are regarded as speakers of Govorka (Anna Urmanchieva and Dieter Stern worked with them when describing Govorka, see Urmanchieva 2010, Stern 2012). The question arises whether the variety of Russian, spoken in the 1990s (when the audiofiles were collected) by the Nganasans, forms a post-pidgin continuum or whether we deal with two different systems. If the hypothesis about a post-pidgin continuum is correct, these varieties of Russian are instances of a mesolect, which form a continuum between the acrolect (the highest or most prestigious variety - in our case Standard Russian) and the basilect (the lowest or least prestigious variety - in our case Govorka, see also Helimski 2000: 381). So, while describing this continuum it may be difficult to distinguish between Govorka influence and Nganasan influence on Russian. The fact that initially Nganasan influenced Govorka complicates this issue even further. Thus, apart from the descriptive aim this paper has the second aim of trying to prove or disprove the existence of a post-pidgin continuum in the area.

The structure of the paper is as follows. Section 2 presents the corpus of contact-influenced Russian speech of the Russian Far East and Northern Siberia and in particular the Nganasan subcorpus. It also gives some basic sociolingustic information on Nganasan. In Section 3, I describe presumable contact induced morphosyntactic features: peculiarities in

\footnotetext{
See Jazyki Rossii v kontakte s russkim jazykom. Available online at $<$ http://web-corpora.net/tsakorpus_russian_nonst $>$. Accessed on 07.12.2020.
} 
the noun and verbal inflection (3.1), as well as in the verbal derivation (3.2), preposition drop and some other peculiarities in the prepositional phrase (3.3), non-standard encoding of subjects in negative existential constructions (3.4), and finally gender mismatches (3.5). Section 4 provides some speculations about the existence of a post-pidgin continuum. Finally, in Section 5, I summarize all the data and draw some conslusions.

\section{The Nganasan language: sociolinguistic situation and the data}

Nganasan people inhabit the Taimyr Peninsula. There are 860 people, who consider themselves to be Nganasans, however only 120 people can actually speak Nganasan, according to Census 2010. Nganasan is an endangered language. All (or almost all) speakers are bilingual and are of the older generations. The Nganasans were traditionally a seminomadic people, but in the 1930s the Soviets instituted a program of collectivization, which resulted in a great change in their lifestyle. In 1938 the first elementary school was opened, and in the 1940s almost all children of school-age received primary education, and many adult Nganasans took special courses as well (Dolgix 1976: 10).

In the paper I analyze Nganasan speech, based on the corpus of contact-influenced Russian speech of the Russian Far East and Northern Siberia. The corpus is being created together with Natalya Stoynova and Polina Pleshak within the larger project "Dynamics of language contact in the circumpolar region" (led by Olesya Khanina). This is a transcribed and annotated collection of oral spontaneous Russian speech of the speakers of Samoyed languages (Forest \& Tundra Enets, Nganasan, Nenets) and of Tungusic languages (Nanai, Ulch, Even) ${ }^{2}$.

The Nganasan Subcorpus consists of narratives in Russian from ten Nganasan speakers, it contains approximately 3.5 hours of transcribed Nganasan Russian ${ }^{3}$. Codes of speakers, their years of birth and the number of clauses in texts collected from each of them follows in Table 1.

Site of the project with the pilot version of the corpus: Jazyki Rossii v kontakte $s$ russkim jazykom. Available online at $<$ http://web-corpora.net/ruscontact/>. Accessed on 07.12.2020.

3 I thank Valentin Gusev for the provided audiofiles. 
Table 1. Speakers' codes, years of birth and the number of clauses in texts collected from each of them

\begin{tabular}{lcc}
\hline Speaker & Year of birth & Clauses \\
\hline MDN & 1923 & 1120 \\
TKF & 1923 & 1278 \\
MVL & 1929 & 431 \\
THL & 1930 & 229 \\
PHL & 1935 & 135 \\
KVB & 1938 & 1375 \\
JSM & 1939 & 184 \\
ChND & 1946 & 1200 \\
KSM & 1949 & 1200 \\
KID & 1966 & 710 \\
\hline
\end{tabular}

As I mentioned in Section 1, since the 19th century the Nganasans spoke the Taimyr Pidgin Russian Govorka (see Stern 2012 on the history of Govorka). In our Nganasan subcorpus two speakers (TKF and $\mathrm{MDN}^{4}$ ) are regarded as speakers of Govorka.

In order to trace the Nganasan influence to the Russian speech of the Nganasans, I used mostly the Nganasan Spoken Language Corpus (NSLC, see Brykina et al. 2018) and the grammar by Tereščenko (1979).

\section{Morphosyntactic phenomena}

This section focuses on morphosyntactic phenomena that are caused by differences between Russian (Slavic $<$ Indo-European) and Nganasan (Samoyedic $<$ Uralic). First, Russian has gender, while Nganasan does not, which leads to non-standard noun inflection (see Subsection 3.1) and non-standard gender marking of adjectives, verbs and pronouns (see Subsection 3.5) in Nganasan Russian. Second, Russian uses a derivational affix $-s^{\prime} a$ to express mediopassive and some other related meanings, while Nganasan uses a reflexive conjugation to express them. This results in non-standard use of $-s^{\prime} a$ in Nganasan Russian

4 It is worth noting that the first language of MDN and TKF is Enets, not Nganasan. 
(see Subsection 3.2). Third, Nganasan and Russian differ in argument encoding (see Subsections 3.3 and 3.4).

\subsection{Noun and verb inflection}

First, some nouns change their morphological gender (or declension class): in (1) the word podarka 'present' has the a-stem declension, typical of feminine nouns instead of the consonant declension, typical of masculine nouns.

(1) Poneset podarku k nej. (JSM) - ACC.FEM, instead of podarok ACC.MASC 'He will bring her a present'.

(NganRus: JSM_09_rus1, 4)

In (2)-(6) we see examples of nonstandard verb inflection: problems with the imperfective affix -ova/-u (2), non-standard verb stem formation (3)-(4), non-standard form of imperatives (5) and non-standard participle forms (6).

(2) Kogda pridet, sobaka radovaets'a, šumit. (MVL) - PRs.3sG, instead of radujets'a

'When he comes, the dog is happy and noisy'.

(NganRus: MVL_09_rus3, 74)

(3) Ja teb'a pobeždu. (KVB) - PRs.1sG, no such form in Standard Russian 'I will defeat you'.

(NganRus: KVB_97_Djuhode_nar-rus, 116)

(4) Ob'azatel'no etim žirom mazaj. (KVB) - IMP.2SG, instead of maž 'By all means lubricate it with this fat'.

(NganRus: KVB_970930_ThreeGirls_flkd-rus, 50)

(5) Ty teper' 'jed'. (KVB) - IMP.2sG, instead of jezžaj

'Now you go'.

(NganRus: KVB_970930_ThreeGirls_flkd-rus, 241)

(6) Eti von vse razorvaty. (KVB) - PST.PTCP.PL, instead of razorvany

'These things are all torn'.

(NganRus: KVB_970930_ThreeGirls_flkd-rus, 216) 
The examples above cannot be exactly attributed to contact-induced under-acquisition of the Russian system, since they are attested in colloquial Russian: see e.g. Kasatkin (2005: 141ff.) on non-standard use of the suffix -ova as in (2) and non-standard consonant alternations as in (3)-(4), Kasatkin (2005: 154) on imperative forms as in (5), and Kasatkin (2005: 172) on participle forms with $t$ as in (6).

\subsection{Derivation}

In the case of nonstandard derivation, the most prominent peculiarity is the omission (7) or the overuse (8) of the reflexive affix $-s^{\prime} a$, a derivational postfix, which is attached after the inflectional affixes, with a wide range of uses, including reflexive, reciprocal, decausative, passive and some others.

(7) A vmesto nego op 'at'eta vot eta vot pov'azka val'ajet (ChND) - instead of val'ajets'a

'And instead of it again this bandage is lying'.

(NganRus: ChND_99_Barusi_flkd-rus, 165)

(8) Davaj ne propadajs'a (KVB) - instead of propadaj

'Don't get lost'.

(NganRus: KVB_97_Djuhode_nar-rus, 114)

The closest (but nevertheless very distant) Nganasan parallel to the Russian derivational affix $-s^{\prime} a$ is an inflectional suffix, namely the so called reflexive (-medial) conjugation. It is used mostly with transitive verbs and its meanings partly overlap with the meanings of Russian -s'a (see Tereščenko 1979: 193-196).

Some omissions of $-s^{\prime} a$ can be explained by the fact that corresponding Nganasan verbs are not used with the reflexive conjugation: compare (7) without $-s^{\prime} a$, and (9) with subjective (and not reflexive) conjugation in the corresponding Nganasan verb from the parallel version of the Russian text. On the other hand, some overuses of $-s^{\prime} a$ can be explained by the presence of the reflexive conjugation in the corresponding Nganasan verb form, compare (8) with $-s^{\prime} a$ and (10) with reflexive conjugation. 
(9)

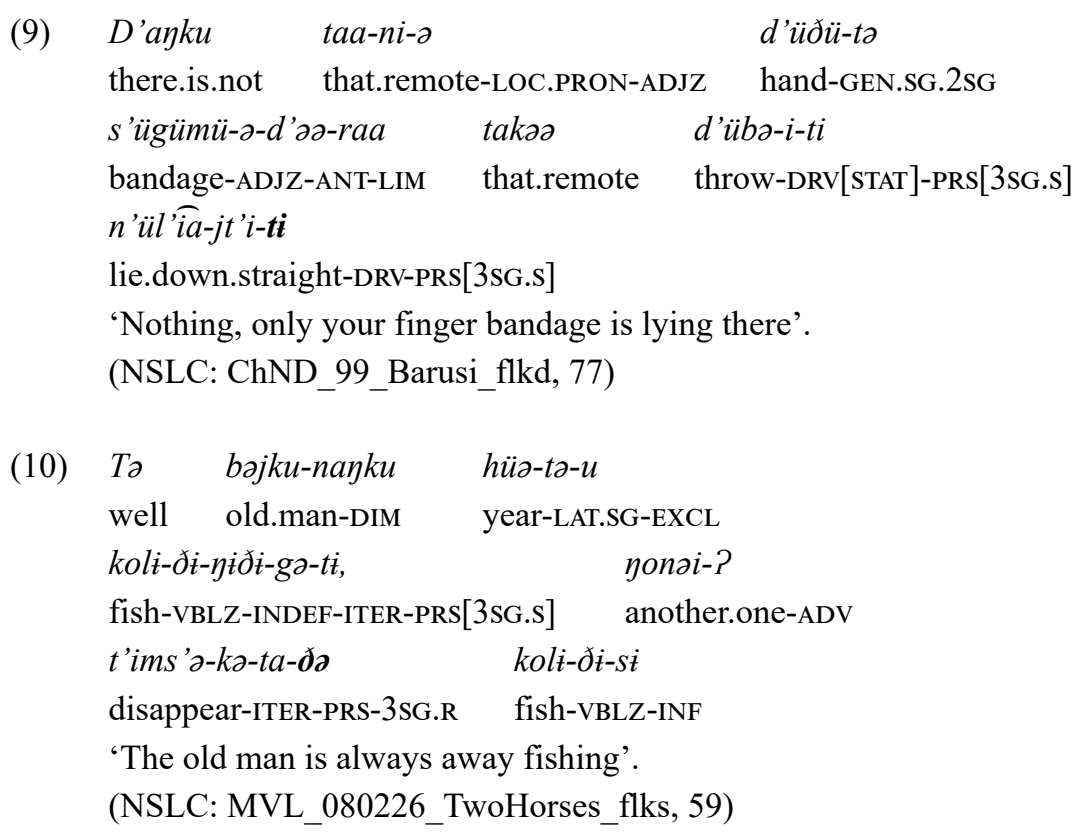

However, in these two examples there might be an alternative explanation. In (7) the relation between the Russian verbs val'at 's' $a$ 'lie' and val'at' 'drag' is not transparent, while in (8) a possible contamination with the Russian reflexive verb ter'at's' $a$ 'get lost' might have played its part.

In a similar manner, in (11)-(12) there could have been a contamination with the Russian verb perepravils' $a$ 'crossed', since the reflexive conjugation in the corresponding (but not equivalent) Nganasan verb is not used (13).

(11) Uže, govor'at, na tot bereg on priplyls'a (KVB) - instead of priplyl 'They say he has already swum up to that river bank'.

(NganRus: KVB_97_Djuhode_nar-rus, 100)

(12) Potom, govor'at, pereplyls'a i rukoj, govor'at, mahnul, čto značit idi. (KVB) - instead of pereplyl

'They say then he swam across the river and waved his hand to show that he should go as well'.

(NganRus: KVB_97_Djuhode_nar-rus, 101) 


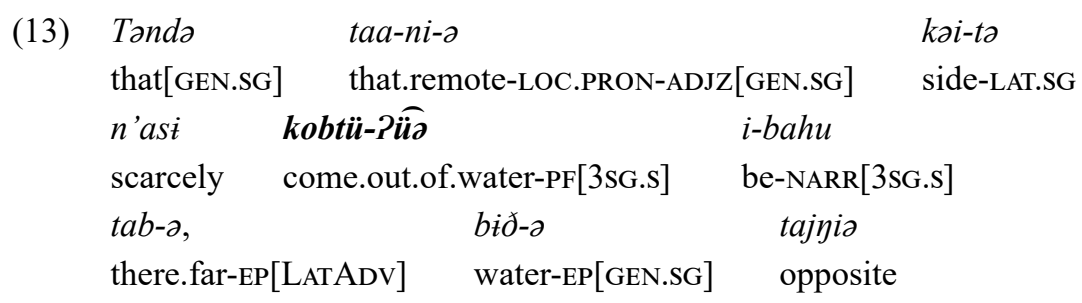

'He barely swam across the river and pulled up to the other river bank'. (NSLC: KVB_97_Djuhode_nar, 60)

Moreover, there are some examples with omission of $-s$ ' $a$ that can be explained by Taimyr Pidgin influence (14)-(16) on the Russian of older Nganasans: in Taimyr Pidgin $-s^{\prime} a$ is regularly omitted (Urmanchieva 2010: 199).

(14) Purga načinal sovsem (MDN) - instead of načinals'a

'The raging blizzard started'.

(NganRus: MDN_97_KillerHill_nar-plus-rus, 18)

(15) Podnimajet, kak budto rast'ot (THL) - instead of podnimajets'a

'It is rising as if it is growing'.

(NganRus: THL_Shaman_flkd-rus, 176)

(16) Kogda men'a sila končajet (MDN) - instead of končajets'a

'When my strength comes to an end'.

(NganRus: MDN_97_Song_song_Pidgin, 82)

These examples cannot be attributed to Nganasan influence, since in Nganasan several verbs that mean the start of an activity have reflexive conjugation (Tereščenko 1979: 195), see also (17).

$\begin{array}{ll}\text { bən'd'ว-P } & n \text { 'ili-l'i-Pi-tว? } \\ \text { all-NOM.PL } & \text { live-INCH-PF-3PL.R }\end{array}$

'Everyone started to live'.

(NSLC: MVL_080304_TwoMeryde_flk, 387)

Some randomness of this $-s$ ' $a$ omission/overuse is confirmed by (18), where we witness two versions of the verb podnimat's' $a$ 'rise' in the same text fragment, and even more by (19), where two versions of the verb otkryt's ' $a$ 'open' are attested in the same sentence. 
(18) Kak budto vverh podnimajets'a. I bol'še = bol'še bol'še <INDISTINCT SPEECH> vot tak. Okružajet bol'še. Bol'še vot tak. Podnimajet, kak budto rast'ot (THL)

'As if he is rising. And more... like this. He encircles it more. More, like this. He is rising, as if he is growing'.

(NganRus: THL_Shaman_flkd-rus, 172-176)

(19) Dver'otkrylas', eto dver'v čumike dver' otkryla (JSM)

'The door opened, the door in the small tent opened'.

(NganRus: JSM_060901_Relationship1_nar-rus, 13)

It is worth noting that the omissions and overuses of $-s^{\prime} a$ are not widespread. In Nganasan Russian there are 8 nonstandard uses of $-s$ ' $a$ and 219 standard ones (which makes $0.04 \%$ of irregularity). A similar percentage is found in Tungusic Russian: there are 46 nonstandard uses of $-s^{\prime} a$ and 687 standard ones (which makes $0.07 \%$ of irregularity), see (Khomchenkova et al. 2019). In Nganasan Russian $-s$ 'a was omitted 5 times and it was overused 3 times. Even on these small numbers one can see that the number of omissions is bigger than the number of overuses, since the reflexive conjugation is rather restricted, not used with many verbs, and thus there is no reason for an overuse of $-s^{\prime} a$. The same pattern is attested both in Samoyedic and Tungusic Russian: according to Khomchenkova et al. (2019), in Samoyedic languages (Tundra and Forest Enets, Nenets and Nganasan) the number of omissions equals 17 and the number of overuses equals 7 correspondingly, while in Tungusic languages (Nanai and Ulch) the number of omissions equals 29, and the number of overuses equals 17.

\subsection{Argument encoding and the use of prepositions}

As one would expect, prepositions in Nganasan Russian are prone to be used in a nonstandard way, owing to the presence of postpositions in Nganasan. First, sometimes the addressee is marked with the preposition $n a$ with a genitive noun form instead of simple dative encoding with verbs of speech (20), which might be the result of an influence of the Nganasan allative postposition as a marker of the addressee of a verb of speech (21). 
(20) Potom on togda govorit na nejo (KVB) - instead of jej

'Then he says to her'.

(NganRus: KVB_970930_ThreeGirls_flkd-rus, 477)

$\begin{array}{lcl}\text { Ni-nti } & \boldsymbol{d} \boldsymbol{a} & \text { munu-ntu: } \\ \text { wife-GEN.SG.3SG } & \text { ALL[LAT.ADV] } & \text { say-PRS[3sG.S] } \\ \text { Büü-gü-ni } & \text { tagaPa } & \\ \text { go.away-IMP-1DU.R } & \text { from.here } & \end{array}$

'He said to his wife: -Let's get out of here'.

(NSLC: MVL_97_Tangka_flkd, 21)

Examples with doubling are also attested (22)-(23): the preposition $n a$ is used not with genitive, but with a dative noun form. Thus, the preposition is used because of the Nganasan influence, but this influence does not spread to the noun form - the dative is still used as in Standard Russian.

(22) Davaj, na žene govorit, ty ničego ne delaj (KVB) - instead of žene

'He says to his wife: do nothing'.

(NganRus: KVB_97_BajShaman-rus, 141)

(23) I govorit etomu na hoz'ainu (KVB) - instead of hoz'ainu

'And he says to the master'.

(NganRus: KVB_97_BajShaman-rus, 240)

Second, sometimes genitive noun forms are used with other Russian prepositions, such as navstreču 'towards', instead of dative (24)-(25). Again this might be a Nganasan pattern, since Nganasan postpositions govern genitive case (Tereščenko 1979: 297), including a construction GEN $+n$ 'era d'a (26). However, the influence of the Russian construction $\mathrm{N}+\mathrm{GEN}$ vstreča otca 'the meeting of the father', vstreča vetra 'the meeting of the wind', cannot be excluded.

(24) Vot navstreču govor'at begut otca (KVB) - instead of navstreču otcu 'They are running towards their father, they say'.

(NganRus: KVB_97_Djuhode_nar-rus, 293)

(25) Id'ot-id'ot navstreču vetra - (KVB) instead of navstreču vetru

'He is walking against the wind'.

(NganRus: KVB_970930_ThreeGirls_flkd-rus, 245) 
(26)

$\begin{array}{lllll}\text { tibijkiâ?ku } & \text { in's'üð } & \text { n'ero } & \text { d'a } & \text { torəmiPiðə } \\ \text { youth-DIM } & \text { sledge[GEN.SG] } & \text { before } & \text { ALL[LAT.ADV] } & \text { run-PF-3SG.R } \\ \text { 'A boy ran towards a sledge'. } & & & \end{array}$

(NSLC: JD_00_TwoDolganBrothers_flk, 272)

Third, in comparative constructions the preposition ot is attested (27): the construction $o t+$ GEN is used instead of genitive without preposition or the construction čem + NOM. This is likely to be a result of Nganasan influence: in Nganasan the ablative marks the standard of comparison (28).

(27) Nikakoj bog ot men'a vyše netu. (KVB) - instead of vyše men'a / vyše čem ja

'There is no God higher than me'.

(NganRus: KVB_97_Djuhode_nar-rus, 140)

(28)

$\begin{array}{lll}\text { Tahariaa } & k u \text {-ni-gal't'i } & \text { anika-Pu-rba?a } \\ \text { now } & \text { which-LOC.PRON-EMPH } & \text { big-AUG-AUG }\end{array}$

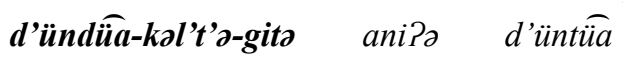

horse-EMPH-ABL.PL big horse

'Totally big, this horse is bigger than [regular] horses'.

(NSLC: MVL_080226_TwoHorses_flks, 264)

Fourth, in Nganasan Russian, preposition drop is attested (for the description of preposition drop in Tundra Enets, Forest Enets and Nanai see Khomchenkova et al. 2017). Different prepositions can be omitted, e.g. $v$ 'in' (29) or $k$ 'to' (30). In Nganasan, the lative case has functions similar to those of the Russian preposition $v(31)$, and the allative postposition has functions similar to those of Russian $k$, see (32) from the parallel version of the text.

(29) Potomu čto on popal... Kapkan deduški l'udojeda (ChND) - ACC.SG, instead of $v$ kapkan

'Because he got caught in the trap of an ogre'.

(NganRus: ChND_0412_Djajku_flkd-rus, 27)

(30) Idi domoj, roditel'am teper'idi (KVB) - DAT.PL, instead of $k$ roditel'am 'Go home, go to your parents now'.

(NganRus: KVB_970930_ThreeGirls_flkd-rus, 413) 


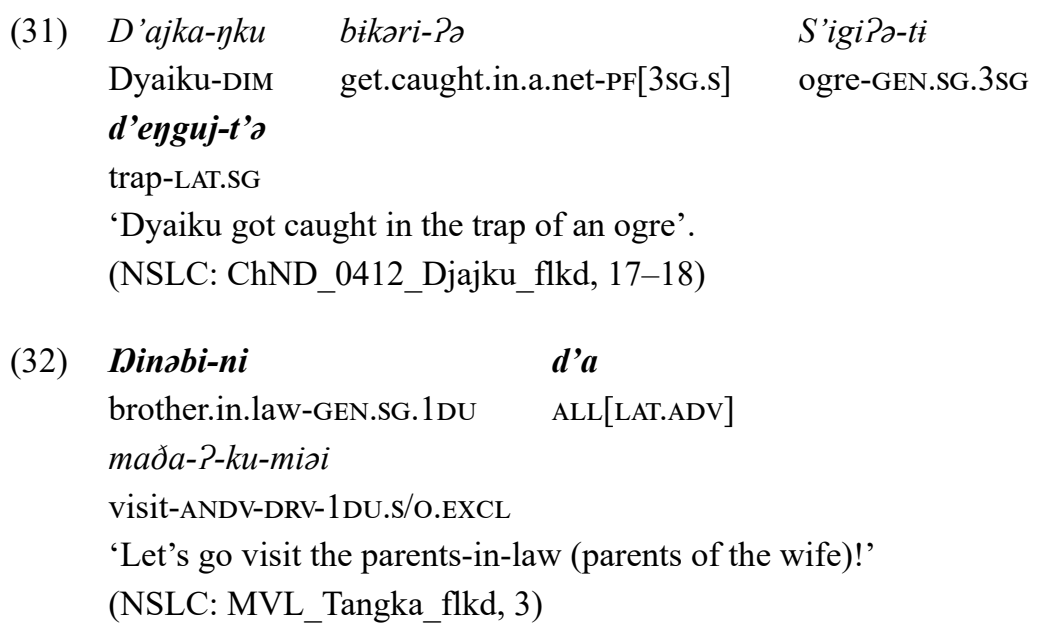

There are two possible explanations of this phenomenon: 1) morphosyntactic influence of $\mathrm{L1}$, and 2) phonetic influence of L1. The first hypothesis is confirmed by the fact that lative corresponds to the Russian prepositional phrases with $v(31)$ - and this factor was mentioned as relevant in Daghestanian Russian (Daniel and Dobrushina 2013) and in Erzya Russian (Shagal 2016). Examples like (30) confirm this hypothesis as well - in Nganasan, in these contexts the allative is used (32). However, the allative is a postposition (Tereščenko 1979: 84-85), see its separate pronominal use:

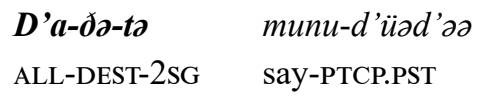

'The one that said to you \{in three years I will cut you neck off \}'. (NSLC: JD_00_TwoDolganBrothers_flk, 485)

The preposition drop might also be explained by phonetic influence of L1: in Nganasan initial consonant clusters are more restricted than in Russian (Tereščenko 1979: 40, Wagner-Nagy 2019: 61). Sometimes $v$-drop occurs in frozen prepositional phrases like vverh (v-verh 'intop'), vper'od (v-per'od 'in-front'), see (34). However, examples with initial $v$ omitted in non-prepositional contexts have not been attested, cf. (35) from Nanai Russian.

(34) Nu čo ty usnula? Idi per'od. (KVB) - instead of vper'od 'So, have you fallen asleep? Go ahead'.

(NganRus: KVB_97_Djuhode_nar-rus, 124) 


\section{(35) Kusn'eje taly - instead of vkusneje}

'It is more tastier than tala (frozen sliced fish)'.

(Nanai Russian, Khomchenkova et al. 2017: 22)

There also can be some interfering factors. For example, sometimes it is difficult to distinguish between the omission of $v$ and non-standard argument structure. For example, in (36)-(38) the preposition drop can be explained by the fact that the Nganasan verb 'hit' is transitive. This fact is especially confirmed by (37): if the preposition had been omitted, the word form nego would be present (from $v$ nego), however, we see a non-prepositional form.

(36) Oni voobš'e ne mogut popadat' nganasan (ChND) - instead of $v$ nganasan

'They cannot hit the Nganasans at all'.

(NganRus: ChND_99_War_flkd-rus, 30)

(37) Poprobujte jego popast'streloj (ChND) - instead of $v$ nego

'Try to hit him with an arrow'.

(NganRus: ChND_99_War_flkd-rus, 54)

(38) Prygal-prygal i nency jego nikak ne mogli popsat' (ChND) - instead of $v$ nego

'He was jumping and the Nenets couldn't hit him at all'.

(NganRus: ChND_99_War_flkd-rus, 67)

In much the same way the preposition drop in (39) can be explained by non-standard argument structure, since the corresponding verb in Nganasan is transitive (40).

(39) Tol'ko men'a smotri (KVB) - instead of na men'a

'Only look at me'.

(NganRus: KVB_97_Djuhode_nar-rus, 81)

\begin{tabular}{|c|c|c|}
\hline Uku-tu & $d^{\prime} a$ & mun-u-bayhu: \\
\hline Uku-GEN.SG.3s & ALL[LAT.ADV] & say-EP-NARR[3sG.S] \\
\hline Mano $\quad s$ & $s \partial t^{\prime} \partial-r-\ddot{u}-P$ & \\
\hline $\mathrm{I}[\mathrm{ACC} . \mathrm{SG}]$ & scrutinize-FRQ-EP-IM & G.S \\
\hline
\end{tabular}

(NSLC: KVB_97_Djuhode_nar, 48) 
Moreover, some potential preposition drops can be explained by a non-standard possessive construction: in (41) the preposition $k$ might have been omitted, because in the corresponding Nganasan sentence possessive marking is used on the goal argument (42).

(41) I jejo etot paren'vz'al za ruku i pov'ol sebe v čum (ChND) - instead of $k$ sebe

'And this guy took her by hand and leaded her to his tent'.

(NganRus: ChND_080729_Mosquitos_flkd-rus, 398)

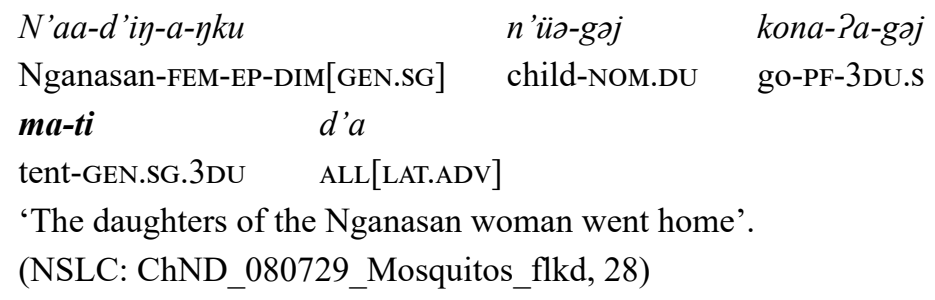

\subsection{Negative existential constructions}

In Standard Russian the subject of the negative existential construction is marked with the genitive case, while in Nganasan it remains in nomitative case (43). Consequently, some speakers prefer nominative case in such contexts in Russian as well (44)-(46). However, it should be noted that negative existential constructions with nominative subject are also possible in Northern Russian dialects (Požarickaja 2005: 166-167).

$\begin{array}{ll}\text { патьи-ðu } & \text { d'anguj-kə-tu } \\ \text { sleep-NOM.SG.3SG } & \text { be.absent-ITER-PRS[3SG.S] }\end{array}$

'(Tanku suffered from insomnia.) There was no sleep'.

(NSLC: MVL_97_Tangka_flkd, 30)

(44) Son daže netu (MVL) - NOM.SG, instead of sna (GEN.SG)

'There was no sleep'.

(NganRus: MVL_97_Tangka_flkd-rus, 226)

(45) A polovina tol'ko, a polovina netu (KVB) - NOM.SG, instead of poloviny (GEN.SG)

'There is only the half, and the other half is missing'.

(NganRus: KVB_97_Djuhode_nar-rus, 202) 
(46) Voda govor'u voobš'e net (THL) - NOM.SG, instead of vody (GEN.SG) 'I say there is no water at all'. (NganRus: THL_Shaman_flkd-rus, 38)

\subsection{Gender mismatches}

Gender mismatches are widely attested in the colloquial Russian speech of bilingual speakers of indigenous languages of Russia, cf. observations by Daniel et. al. (2010: 76-77) on Daghestanian Russian, Shagal (2016) on Erzya Russian and also by Daly (1986) on Ninilchik Russian. Nganasan has the same feature - there are many gender mismatches in Nganasan Russian due to the absence of the category of gender in Nganasan.

Standard Russian distinguishes three genders: masculine, feminine and neuter. For sex-differentiable nouns the choice (between $M$ and F) is semantically determined, for the others the choice (between F, M and N) is arbitrary. Both for sex-differentiable nouns and non-differentiable ones a partial correlation between gender and noun declension type takes place, see, for example, Corbett (1982, 1991: 34ff.) for the rules of case assignment in Russian. Gender is manifested in a) adjectives (and adjectivelike words), b) verbs (in past tense forms), c) personal pronouns.

In Nganasan Russian, all possible types of gender mismatches are attested: examples (47)-(48) present gender-mismatch in adjective-like words, both in attributive and in predicative position, in (49) there is a verb with gender mismatch and in (50) a different personal pronoun is used.

(47) Ni odnu kusoček ne kušajet (KVB) - F, instead of odin M

'She isn't eating not even one piece'.

(NganRus: KVB_970930_ThreeGirls_flkd-rus, 313)

(48) Kakoj pr'am jeda-to horošij sovsem (KVB) - $\mathrm{M}$, instead of kakaja $\mathrm{F}$ and horošaja $\mathrm{F}$

'How tasty the food is'.

(NganRus: KVB_970930_ThreeGirls_flkd-rus, 122)

(49) Staruha govorit: ja ž tebe govoril (ChND) - M, instead of govorila $\mathrm{F}$

'The old woman says: I knew I was right'.

(NganRus: ChND_0412_Djajku_flkd-rus, 83) 
(50) Eta... N'urka-to. On p'jot sovsem (MVL) - M, instead of ona F 'This... Njurka. She has a drinking problem'.

(NganRus: MVL_09_rus1, 23)

In the examples above there are two types of mismatches: $\mathrm{M}>\mathrm{F}$ in (47) and $F>M$ in (48)-(50). Examples of the type $N>M(51)$ and of $\mathrm{N}>\mathrm{F}(52)-(53)$ are also attested.

(51) I m'aso takoj kipit sovsem (MVL) - M, instead of takoje $\mathrm{N}$

'And the meat is boiling'.

(NganRus: MVL_97_Tangka_flkd-rus, 147)

(52) Pojd'om von ozero bol'šaja (JSM) - F, instead of bol'šoje N

'Let's go to that big lake'.

(NganRus: JSM_060901_Relationship1_nar-rus, 28)

(53) Žena govorit eto tvoja delo (MVL) - F, instead of tvojo $\mathrm{N}$

'The wife says: it's your business'.

(NganRus: MVL_97_Tangka_flkd-rus, 237)

The examples (52) and (53) also might have a different and more probable explanation: in Russian, nominative suffixes of neuter nouns of the o-type declension and those of feminine nouns of the a-type have the same phonetic realization - the speakers might have reanalyzed the gender of words ozero 'lake' and delo 'affair' as feminine.

It is worth mentioning that there is no general nonstandard system of gender mismatches, rather there is considerable variation across speakers. For example, the youngest speaker KID (born 1966) sometimes uses the masculine past form of the verb byt' 'be' with nonmasculine nouns:

(54) Togda p'janka byl u nas (KID) - PST.SG.M, instead of byla PST.SG.F 'Then we had a drunken feast'.

(NganRus: KID_2009_mb_ded_rus2, 236)

(55) A u nego odna noga byl že (KID) - PST.SG.M, instead of byla PST.SG.F 'And he had one leg'.

(NganRus: KID_2009_mb_ded_rus2, 264) 
However, even with this great variation across speakers there are some hierarchies that apply to most speakers:

- adjectives $>$ verbs $>$ pronouns (higher $\%$ of mismatches $>$ lower $\%$ of mismatches);

- non-humans $>$ humans (higher $\%$ of mismatches $>$ lower $\%$ of mismatches);

- masculine $>$ feminine $>$ neuter (non-masculine forms most often become masculine)

These hierarchies apply even with the great variation across Nganasan, Ulch, Nanai and Forest Enets (for more detailed numerical data on these languages see Khomchenkova et al. 2018).

\section{Post-pidgin continuum}

As it was mentioned in the introduction, in the Nganasan subcorpus two speakers are regarded as speakers of Govorka (MDN and TKF) and it is unclear whether the varieties of Russian spoken in the 1990s (when the audiofiles were collected) by the Nganasans form a postpidgin continuum or do we see two different systems now. According to Helimski (2000: 381), when he was describing Govorka the postpidgin continuum did already exist, and because Govorka speakers had become acquainted with Russian speech and sometimes used its fragments, this resulted in frequent code-switching between Govorka and Russian, which complicates this issue even more.

According to Urmanchieva (2010) and Stern (2012), features that are considered to be striking features of Govorka are the following: the use of postpositions instead of prepositions, analytic future tense, attributive constructions (non-marked dependent + head), lack of gender agreement, the omission of the reflexive affix $-s^{\prime} a$ and non-marking of number and case on nouns.

I will try to address this question mainly from gender mismatches data, since this feature is the most striking and others peculiarities are found more rarely. I analyzed the data from three speakers: MDN, who was regarded as a (mesolect) Govorka speaker by Stern (2012), and 
MVL and KVB, since they represent three different age groups and there are the most data from them ${ }^{5}$.

In Govorka, adjectives do not agree with nouns, they have only masculine forms (Helimski 2000: 385), while verbs can have different gender forms, but they are not used systematically (Helimski 2000: 391). Indeed, according to Table $2, \mathrm{MDN}$ prefers $\mathrm{m}$-forms, but f-forms and $\mathrm{n}$-forms are present as well (especially in verbs).

Table 2. Types of gender mismatches in adjectives and verbs. Percentages indicate the overall number of errors in gender assignment

\begin{tabular}{|c|c|c|c|c|c|c|c|c|}
\hline & \multicolumn{4}{|c|}{ ADJ } & \multicolumn{4}{|c|}{ V } \\
\hline & $M>F$ & $\mathrm{~F}>\mathrm{M}$ & $\mathrm{N}>\mathrm{M}$ & $\mathrm{N}>\mathrm{F}$ & $\mathrm{M}>\mathrm{F}$ & $\mathrm{F}>\mathrm{M}$ & $\mathrm{N}>\mathrm{M}$ & $N>F$ \\
\hline $\begin{array}{l}\text { MDN } \\
1923\end{array}$ & $0 \%$ & $71 \%$ & $86 \%$ & $0 \%$ & $6 \%$ & $53 \%$ & $67 \%$ & $0 \%$ \\
\hline $\begin{array}{l}\text { MVL } \\
1929\end{array}$ & $18 \%$ & $35 \%$ & $56 \%$ & $6 \%$ & $4 \%$ & $27 \%$ & $0 \%$ & $0 \%$ \\
\hline $\begin{array}{l}\text { KVB } \\
1938\end{array}$ & $5 \%$ & $24 \%$ & $7 \%$ & $0 \%$ & $10 \%$ & $10 \%$ & $0 \%$ & $0 \%$ \\
\hline
\end{tabular}

Since the second half of the 20th century Standard Russian has become prevalent. Thereafter, in the speech of MVL there is chaos not only in verbal forms, but also in adjectives: $\mathrm{M}$-forms are still widespread, but other transitions like $\mathrm{M}>\mathrm{F}$ and $\mathrm{N}>\mathrm{F}$ become possible. Then the speech of KVB is distinguished by very rare mismatches - she shows almost standard Russian use. Therefore, we get the following mismatches hierarchy: numerous, uniform $>$ numerous, chaotic $>$ rare, chaotic, so this hierarchy might be a confirmation of a continuum hypothesis.

Let us now turn to other features of Govorka. The use of postpositions instead of prepositions is attested only in the speech of MDN and TKF (56)-(57). The postposition mesto, the most prominent Govorka feature according to Helimski (2000: 389), corresponds to Samoyedic lative, locative, ablative and prolative cases, as well as to the Nganasan

\footnotetext{
Unfortunately, there is not much information on their sociolinguistic background. They all lived in Voločanka. MDN was born at the right bank of the Yenisei (near v. Gol'čika), while MVL and KVB were born at the Avam Tundra, and MVL lived in the tundra until the seventies. It is also known that KVB has only primary education.
} 
allative postposition, including their non-locative uses (see more in Urmanchieva 2010, Gusev 2012).

(56) Tut reka mesto stojat von (TKF)

'Here they are standing near the river'.

(NganRus: TKF_99_hibula_rus, 329)

(57) Gagar-to zeml'a mesto ne hodit (MDN)

'Loons do not walk on the ground'.

(NganRus: MDN_97_TwoBirds_flkd-rus, 97)

Analytic future tense (58) and attributive constructions (non-marked dependent + head) (59)-(60) are also attested in their speech, as well as the frequent omission of $-s^{\prime} a(61)$, which was discussed in Section 3.2.

(58) Men'a ubit' budet vs'o ravno teb'a ubit' budet (MDN)

'If I get killed, you will get killed too'.

(NganRus: MDN_97_War1_nar-rus, 23)

(59) Čelovek im'a kakoj-to eto... (TKF)

'The man's name is something like this...'

(NganRus: TKF_99_hibula_rus, 417)

(60) U! Kak eto, zeml'a dyra (MDN)

'Oh! What is it called, the hole in the ground'.

(NganRus: MDN_97_Song_song_Pidgin, 55)

(61) Purga načinal sovsem (MDN)

'The raging blizzard started'.

(NganRus: MDN_97_KillerHill_nar-plus-rus, 18)

Also in their speech there are many nouns, non-marked for number and case, while prepositional phrases and marked for number and case nouns are rare.

(62) Potom olen' teper' tut pla = plavali (TKF) - SG, instead of oleni PL

'Then deer swam here'.

(NganRus: TKF_99_hibula_rus, 38) 
(63) Noga-to vot takije (MDN) - SG, instead of nogi PL 'Feet are like this'.

(NganRus: MDN_97_TwoBirds_flkd-rus, 94)

(64) Odin reb'onok eto, kačalka sidit, kačalka... ne hodit (TKF) - instead of v kačalke

'One child sits in the wheelchair, the wheelchair... he cannot walk'.

(NganRus: TKF_99_hibula_rus, 16-17)

Some of these features are attested in the speech of THL: future tense (65), attributive constructions (66), the omission of $-s^{\prime} a(67)$.

Poprobovat'budu (THL) - instead of poprobuju

'I will try'.

(NganRus: THL_Shaman_flkd-rus, 101)

(66) Sdelajte vot eti... Gusi kryl'ja (THL) - instead of gusinyje kryl'ja

'Make these... goose wings'.

(NganRus: THL_Shaman_flkd-rus, 89)

(67) Bol'še vot tak, podnimajet, kak budto rast'ot (THL) - instead of podnimajets' $a$

'More, like this, he is raising as if he is growing'.

(NganRus: THL_Shaman_flkd-rus, 176-177)

THL was born in 1930, while MVL was born in 1929 and it seems that it would be logical to unite them in one group. However, I have not come across such peculiarities in MVL's speech. Still, the analysis of MVL gender mismatches shows that her speech is more close to Govorka than the speech of others. It would be logical to compare gender mismatches of MVL and THL, but the number of clauses from THL is rather small - if some types of gender mismatches are not attested, this might be because of the text size limitation. We come across an analogous problem with PHL (born 1935) - the text from this speaker is even smaller than the text from THL. Again THL's speech lacks the features, that are typical of Govorka and there is no sense in counting gender mismatches because of the text size. 
The speech of KVB (born 1938) again lacks Govorka features, and her types of gender mismatches are rather limited, but there are many texts from her, so this hardly is a coincidence. Moreover, her speech is very coherent and cohesive in contrast to many others' speech. The text size from JSM (born 1939 or 1944) is small, so we cannot prove or disprove anything from this data. Then there are many texts from ChND (born 1946) - her speech is coherent and cohesive as well. The size of the text from KSM (born 1949) is very small again.

To sum up, the text size limitations do not permit to rely on some quantitative data about Govorka features or types of gender mismatches and thus it does not seem that it is possible to draw a distinct line between Govorka speakers and the others, basing only on the year of birth. However, if we take into consideration only speakers, from whom we have many data, we will have the following picture, illustrated in the Table 3 .

Table 3. Codes, years of birth and number of clauses from speakers who produced longer texts; $\mathrm{G}$ - (almost) Govorka speaker, $(\mathrm{G})$ - some features of Govorka, * - no features of Govorka

\begin{tabular}{lccccccc}
\hline Speaker & MDN & TKF & MVL & THL & KVB & ChND & KID \\
\hline Y.o.b & 1923 & 1923 & 1929 & 1930 & 1938 & 1946 & 1966 \\
Clauses & 1120 & 1278 & 431 & 229 & 1375 & 1200 & 710 \\
Govorka & G & G & $(G) / *$ & $(G)$ & $*$ & $*$ & $*$ \\
\hline
\end{tabular}

This picture reminds of some kind of continuum: TKF and MDN are speakers of Govorka, then MVL and THL have some Govorka features in their speech, and finally the speech of KVB, ChND and KID is the closest to standard Russian. Now we can postulate either a continuum, composed of all speakers' idiolects, or a continuum composed of TKF, MDN, MVL and THL, followed by a drastic change from Govorka to Russian. Nevertheless, from the available data it seems that it is impossible to make a decision between these two variants. 


\title{
5. Conclusion
}

I have investigated the variety of Russian spoken by the Nganasans, basing on the Nganasan subcorpus of narratives from the larger corpus of contact-influenced Russian speech of the Russian Far East and Northern Siberia. The study focuses on morphosyntactic phenomena, namely the peculiarities in noun and verbal inflection, verbal derivation, preposition drop, non-standard verb argument encoding, gender disagreement and some others, that presumably are contact-induced. I made an attempt to explain these frequent features of Nganasan Russian appealing to the Nganasan language data.

The second aim of this paper was to speculate as to whether the varieties of Russian spoken in 1990s (when the audiofiles were collected) by the Nganasans form a post-pidgin continuum, with Govorka as the basilect and Standard Russian as the acrolect. Because of the limited amount of data it is impossible to make a sound judgment. Nevertheless, I am of the opinion that at least some speakers constitute a post-pidgin continuum, since they have some Govorka features in their speech.

\section{Acknowledgements}

I would like to express my gratitude to Valentin Gusev, Gerson Klumpp and Natalya Stoynova for their valuable comments.

This study was supported by RSF grant No17-18-01649.

\author{
Address \\ Irina Khomchenkova \\ Volkhonka, $18 / 2$ \\ 119019, Moscow, Russia \\ E-mail: irina.khomchenkova@yandex.ru
}

\begin{abstract}
Abbreviations
1, 2, 3 - 1st, 2nd, 3rd person, ABL - ablative, ADJZ - denominal adjective, ADV - adverbializator, ALL - allative, ANDV - andative, ANT -
\end{abstract}


anterior, AUG - augmentative, DEST - destinative, DIM - diminutive, DRV - derivational affix, DU - dual, EMPH - emphatic, EP - ephentetic vowel, EXCL - exclamative, F - feminine, FEM - denominal nomen: female, FRQ - frequentative, GEN - genitive, IMP - imperative, INCH inchoative, INDEF - indefinite, INF - infinitive, ITER - iterative, LAT, LATADV - lative, LIM - limitative, LOCPRON - locative, M - masculine, $\mathrm{N}$ - neuter, NARR - renarrative, NOM - nominative, $\mathrm{PF}$ - present perfect, PL - plural, PRS - present, PTCP - participal, PST - past, $\mathrm{R}$ - reflexive conjugation, $\mathrm{S}$ - subjective conjugation, $\mathrm{s} / \mathrm{O}$ - subjective-objective conjugation, SG - singular, STAT - stative, vBLZ - verbalizer

\section{References}

Brykina, Maria, Valentin Gusev, Sándor Szeverényi, and Beáta Wagner-Nagy (2018) Nganasan Spoken Language Corpus (NSLC). Archived in Hamburger Zentrum für Sprachkorpora. Version 0.2. Publication date 2018-06-12. Available online at $<$ http://hdl.handle.net/11022/0000-0007-C6F2-8>. Accessed on 07.11.2020.

Corbett, Greville (1982) "Gender in Russian: an account of gender specification and its relationship to declension”. Russian Linguistics 6, 197-232. https://doi.org/10.1007/BF03545848

Corbett, Greville (1991) Gender. Cambridge: Cambridge University Press.

Daly, Conor (1986) "Evonajmat' ves'noc television karaulil - his mother watched TV all night long: on the loss of gender as a grammatical category in Alaskan Russian". Paper presented at California Slavic Colloquium, UC Berkeley.

Daniel, Michael, Nina Dobrushina, and Sergey Knyazev (2010) “Highlanders' Russian: case study in bilingualism and language interference in Central Daghestan". Slavica Helsingiensia 40, 68-97.

Daniel, Michael and Nina Dobrushina (2013) "Russkij jazyk v Dagestane: problemy jazykovoj interferencii”. [The Russian language in Daghestan: problems of language interference.] In Computational Linguistics and Intellectual Technologies, 12. Papers from the annual international conference "Dialogue", 186-211. Moscow: RSUH.

Dolgix, Boris (1976) Mifologičeskije skazki i istoričeskije predanija nganasan. [Mythological tales and historical legends of the Nganasans.] Moscow: Nauka.

Gusev, Valentin Ju. (2012) "O proisxozhdenii nekotoryx elementov Govorki (russkogo tajmyrskogo pidzhina)". [About the origin of some Govorka (Russian Taimyr pidgin) elements.] Vestnik TGPU [TSPU Bulletin] 1, 116, 106-109.

Helimski, Evgenij A. (2000) “'Govorka' - taimyrskij pidžin na russkoj leksičeskoj osnove". [Govorka - Taimyr peninsula Russian-based pidgin.] In E. A. Helimski, ed. Komparativistika, uralistika. Lektsii i stat'i, 378-395, [Comparativistics, Uralistics. Lectures and articles.] Moscow: Jazyki russkoj kultury. 
Khomchenkova, Irina, Polina Pleshak, and Natalya Stoynova (2017) "Non-standard expression of spatial semantics in the contact influenced Russian speech of Far East and Northern Siberia". Language Contact in the Circumpolar World, Moscow, October 26-30, 2017. Book of abstracts, 26-27.

Khomchenkova, Irina, Polina Pleshak, and Natalya Stoynova (2018) “Gender disagreement in the contact-influenced Russian of Northern Siberia and Russian Far East". Theoretical and Experimental Approaches to Gender, Berlin, 14-15.06.2018. Available online at $<$ https://drive.google.com/file/d/1G_ ZrDvAh0DnZN31E2FIe2sFfWD5GyB_X/view>. Accessed on 01.02.2019.

Khomchenkova, Irina, Polina Pleshak, and Natalya Stoynova (2019) "Nonstandard use of the 'reflexive' affix -sja in Russian speech of bilingual speakers of Northern Siberia and The Russian Far East". Languages 4, 2, 39.

https://doi.org/10.3390/languages4020039

Požarickaja, Sofia K. (2005) Russkaja dialektologija: učebnik. [Russian dialectology: a course book.] Moscow, Paradigma.

Shagal, Ksenija (2016) Contact-induced grammatical phenomena in the Russian of Erzya speakers. In K. Shagal and H. Arjava, eds. Mordvin languages in the field,363-377. (Uralica Helsingiensia, 10.) Helsinki.

Stern, Dieter (2005) "Taimyr Pidgin Russian (Govorka)". Russian Linguistics 29, 3, 289-318. https://doi.org/10.1007/s11185-005-8376-3

Stern, Dieter (2012) Tajmyr-Pidgin-Russisch. Kolonialer Sprachkontakt in Nordsibirien. (Studies on Language and Culture in Central and Eastern Europe, 19.) München: Verlag Otto Sagner.

Stoynova, Natalya (in press) Russian in contact with Southern Tungusic languages: evidence from the contact Russian corpus of Northern Siberia and the Russian Far East.

Stoynova, Natalya and Andrej Shluinskiy (2010) "Russian speech of the Forest Enets: sketches by researchers of a moribund language". Slavica Helsingiensia 40, 153-65.

Tereščenko Natal'ja M. (1979) Nganasanskij jazyk. [Nganasan language.] Leningrad: Nauka.

Urmanchieva, Anna Ju. (2010) “Govorka: primer strukturno smešannogo jazyka”. [Govorka: an example of a structurally mixed language.] In Instrumentarij lingvistiki: Sociolinguistic Approaches to Non-Standard Russian. (Slavica Helsingiensia, 40.) Helsinki.

\section{Kokkuvõte. Irina Xomtšenkova: Kontaktist tingitud jooned nganassaa-} nide venekeelses kõnes. Selles artiklis uuritakse nganassaanide kõneldavat vene keele varianti. Töö põhineb narratiividel, mis on pärit suuremast Venemaa Lähis-Ida ja Põhja-Siberi suulise vene keele korpusest, mis sisaldab just kontaktist mõjutatud vene keele näiteid, sealhulgas ka nganassaanide kõneldud vene keele allkorpust. Uurimus keskendub morfosüntaktilistele nähtustele, sealhulgas eripäradele noomenite ja verbide inflektsioonis, verbituletuses, 
prepositsioonide väljajätus, mittestandardses verbi argumentide kodeerimises, soo mitteühildumises jms, mis on eeldatavasti kontaktist tulenevad - neid võib seletada otsese strukturaalse kopeerimisega (otsesed paralleelid nganassaani keeles) või vene keele mittetäieliku omandamisega (ilma otseste paralleelideta nganassaani keeles). Uurimuse teine eesmärk on spekuleerida, kas 1990ndatel kogutud keelenäidete põhjal moodustavad selleaegsed nganassaanide kõneldud vene keele variandid pidžini-järgse kontiinumi, milles govorka ehk Taimõri poolsaare pidžinvene keel on vähemprestiižne keelevariant ja vene kirjakeel on prestiižne keelevariant.

Märksõnad: keelekontakt, grammatiline sekkumine, korpuslingvistika, vene keel, nganassaani keel, govorka, pidžin, samojeedi keeled

\begin{abstract}
Аннотация. Ирина Хомченкова: Интерференция в русской речи нганасанов. Данная статья представляет обзор русского языка нганасанов, основанный на нганасанском подкорпусе нарративов из корпуса контактно-обусловленной русской речи билингвов - носителей малых языков Севера Сибири и Дальнего Востока. Исследование сфокусировано на морфосинтаксических феноменах, а именно нестандартности в именном и глагольном словоизменении, глагольном словообразовании, на опущении предлогов, нестандартном кодировании аргументов глагола, рассогласовании по роду и некоторых других, которые предположительно контактно обусловлены - их употребление может быть объяснено либо с помощью прямого структурного копирования (с явными параллелями в нганасанском), либо с помощью неполного усвоения русского (без явных параллелей в нганасанском). Вторая цель работы - это обсуждение того, образуют ли варианты русского языка нганасанов в 1990-х гг. (когда были записаны аудиозаписи) постпиджинный континуум, где говорка является базилектом, а стандартный русский - акролектом.
\end{abstract}

Ключевые слова: языковые контакты, грамматическая интерференция, корпусная лингвистика, русский, нганасанский, говорка, пиджин, самодийские языки 